\title{
Mental Health Status of Hostlers and Non-Hostlers in relation to
}

\section{Academic Achievement}

\author{
Rizwan Hassan Bhat ${ }^{1}$, Dr. Syed Ahmad Shah ${ }^{2}$
}

\section{ABSTRACT:}

This study was conducted to evaluate the mental health status of Hostlers and Non- Hostlers in relation to their academic achievement.. Sample random sampling method was used in this study to obtain applicable and clear-cut information. The sample of the study includes 160 students selected by sample random sampling from the Aligarh Muslim university .The mental health was measured by means of the Mental Health inventory (MHI),developed by jadish and srivastav,1995.The participants 'previous two years academic achievement scores were used for assessing their academic achievement. The first finding of the study showed that academic achievement appeared as a significant predictor of mental health among hostlers .It means that there is a significant positive correlation ' $R$ ' $=.931$ between academic achievement and mental health among hostlers ,The second finding also showed that academic achievement appeared as a significant predictor of mental health among non- hostlers, It means that there is a significant positive correlation ' $\mathrm{R}$ ' $=.491$ between academic achievement and mental health among nonhostlers. The results also reveal that hostlers showed significantly better academic achievement and mental health when compared with non- hostlers. For the analysis of the obtained data, simple linear regression analysis and t-test was used.

Keywords: Mental Health, Academic Achievement, Hostlers and Non-Hostlers.

\section{INTRODUCTION:}

Mental health is defined as a state of Well-being in which each individual realizes his or her potential, can deal with the usual stresses of life, can work productively and fruitfully, and is able to make a contribution to his or her community. It is the capability to feel, think and act in ways that enhance one's ability to enjoy life and contract with challenges. Expressed in a different way, mental health refers to various capacities including the ability to: understand oneself and one's life; relate to other people and respond to one's environment, experience pleasure and enjoyment; handle stress and withstand discomfort; evaluate challenges and problems; pursue goals and interests; and explore choices and make decisions.

\footnotetext{
${ }^{1}$ M.A Iv.SEMESTER, Department of Psychology, Aligarh Muslim University, Aligarh, U.P

${ }^{2}$ Assistant professor Lovely professional University
} 
Mental health is an integral part of our well-being, yet mental health issues have been unhappily neglected in India. Even worse is the fact that serious mental illnesses are not treated early and the treatment gap even for such disorders is very large. It is well known that people in disadvantaged situations have high levels of mental morbidity and poor access to treatment. Prisons and other custodial institutions are locations which see high levels of mental distress and morbidity. Mental distress may occur in otherwise normal individuals in response to the stress of imprisonment. They may occur in helpless individuals who have pre-existing illness that gets exacerbated in prisons, or develops a new in prisons as a result of stress or other factors. Persons with certain types of personality disorders are also more probable to enter prisons. Given that many of these vulnerabilities are allied with the use of both licit and illicit drugs, it would be expected that these pre-dispositions would also enter the prison along with the prisoner. This adds to the already high burden of substance use (tobacco, alcohol etc.) encountered in prison.

\section{Academic Achievement}

Academic achievement may be defined as brilliance in all academic disciplines, in class as well as co- curricular activities It includes excellence in sporting behavior, confidence, communication skills, punctuality, arts, culture and the like which can be achieved only when an individual is well adjusted. Trow (1956) defined academic achievement as "knowledge attaining ability or degree of competence in school tasks usually measured by standardized tests and expressed in a grade or units based on pupils' performance". Good (1959) refers to academic achievement as, "The knowledge obtained or skills developed in the school subjects usually designed by test scores or marks assigned by the teacher". Mehta K.K. (1969) defined academic achievement as "academic performance includes both curricular and co-curricular performance of the students. It indicates the learning outcome of the students. In class rooms students performs their potentials proficiently as a result of it, learning takes place". The learning outcome changes the behavior pattern of the student through different subjects

Academic achievement is the utmost performance in the entire activities at school after a period of training. Steinberg and Merriam (1993) "Achievement encompasses student ability and performance; it is multidimensional; it is intricately related to human growth and cognitive, emotional, social, and physical development; it reflects the whole child; it is not related to a single instance, but occurs across time and levels, through a student's life in public school and on into post secondary years and working life.". Webster defines achievement as "the quality and quantity of a student's work.".

\section{OBJECTIVES:}

1) To ascertain the influence of academic achievement on mental health among Hostlers.

2) To find out the Influence of academic achievement on mental health among Non-Hostlers

3) To see the difference between hostlers and non hostlers in terms of their Academic Achievement. 
4) To find out the difference between hostlers and non hostlers in terms of their mental health.

On the basis of the above mentioned objectives the following research questions were formulated:

1) Is there any influence of academic achievement on mental health among hostlers?

2) Is there any influence of academic achievement on mental health among non hostlers?

3) Is there any difference between hostlers and non hostlers on the basis of their academic achievement?

4) Is there any difference between hostlers and non hostlers on the basis of their mental health?

\begin{tabular}{|c|c|c|c|c|}
\hline \multicolumn{5}{|c|}{ Model Summary } \\
\hline \multirow[b]{3}{*}{ Model } & \multirow[b]{3}{*}{$\mathrm{R}$} & \multirow[b]{3}{*}{ R Square } & \multirow{3}{*}{$\begin{array}{l}\text { Adjusted } \\
\text { Square }\end{array}$} & Change Statistics \\
\hline & & & & Square \\
\hline & & & & Change \\
\hline 1 & $.931^{\mathrm{a}}$ & .867 & .865 & .867 \\
\hline
\end{tabular}

The above table shows Simple Linear Regression analysis of Academic achievement, it showed that Academic achievement appeared as significant predictor of mental health. It was found that Academic achievement (Predictor) emerged to influence significantly the hostlers' Mental health (Criterion). This table shows the model summary, which indicates one predictor of the model. The correlation was found to be $\mathrm{R}=.931$. $\mathrm{R}$ Square change mentioned in the above table indicates the actual contribution of predictor variable to the criterion variable. Therefore the original covariance, the magnitude of independent variable which contributed to the dependent variable (Mental health) came out as $86.7 \%$.

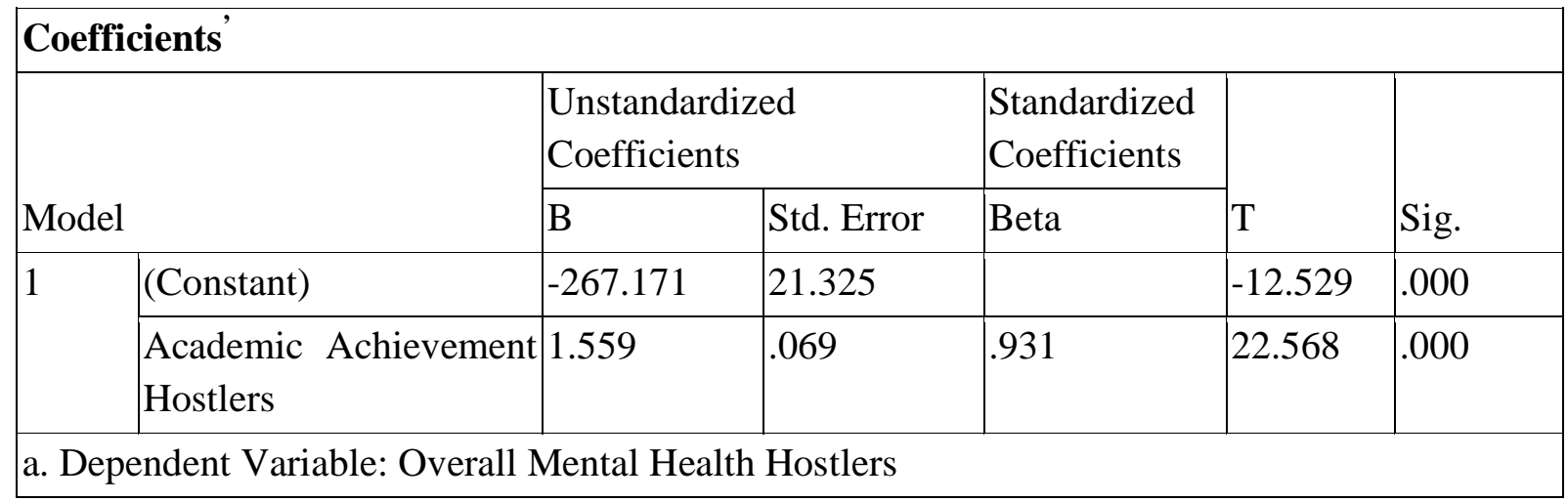

The above table clearly shows that Academic achievement, the predictor variable influences mental health (Criterion). The Statistical value given in the table was found significant for above mentioned predictor that is Academic achievement indicating a relationship between predictor and criterion variable mental health. The value of Partial Correlation is $r=.931$, therefore predictor significantly influenced the degree of Mental health; this finding indicates that Academic achievement appeared as a significant factor of Mental health among Hostlers. The table indicates a significant positive correlation exists between Academic achievement and 
mental health among Hostlers. It means that when Academic achievement increases mental health also increases and when Academic achievement decreases Mental health also decreases.

\begin{tabular}{|c|c|c|c|c|}
\hline \multicolumn{5}{|c|}{ Model Summary } \\
\hline Model & $\mathrm{R}$ & R Square & $\begin{array}{l}\text { Adjusted } \\
\text { Square }\end{array}$ & \begin{tabular}{l|l} 
& Change \\
$\mathrm{R}$ & Statistics \\
Square Change
\end{tabular} \\
\hline 1 & $.491^{\mathrm{a}}$ & .241 & .231 & .241 \\
\hline
\end{tabular}

The above table shows Simple Linear Regression analysis of Academic achievement, it showed that Academic achievement appeared as significant predictor of mental health. It was found that Academic achievement (Predictor) emerged to influence significantly the nonhostlers' Mental health (Criterion). This table shows the model summary, which indicates one predictor of the model. The correlation was found to be $\mathrm{R}=.491 \mathrm{R}$ Square change mentioned in the above table indicates the actual contribution of predictor variable to the criterion variable. Therefore the original covariance, the magnitude of independent variable which contributed to the dependent variable (Mental health) came out as $24.1 \%$.

\section{Coefficients'}

\begin{tabular}{|c|c|c|c|c|c|c|}
\hline & & \multicolumn{2}{|c|}{$\begin{array}{l}\text { Unstandardized } \\
\text { Coefficients }\end{array}$} & \multirow{2}{*}{\begin{tabular}{|l}
$\begin{array}{l}\text { Standardized } \\
\text { Coefficients }\end{array}$ \\
Beta
\end{tabular}} & \multirow[b]{2}{*}{$\mathrm{T}$} & \multirow[b]{2}{*}{ Sig. } \\
\hline \multicolumn{2}{|c|}{ Model } & $B$ & Std. Error & & & \\
\hline \multirow[t]{2}{*}{1} & (Constant) & 114.714 & 17.360 & & 6.608 & .000 \\
\hline & $\begin{array}{l}\text { Academic Achievement } \\
\text { Non-Hostlers }\end{array}$ & .261 & .052 & .491 & 4.976 & .000 \\
\hline
\end{tabular}

The above table clearly shows that Academic achievement, the predictor variable influences mental health (Criterion). The Statistical value given in the table was found significant for above mentioned predictor that is Academic achievement indicating a relationship between predictor and criterion variable mental health. The value of Partial Correlation is $r=.491$, therefore predictor significantly influenced the degree of Mental health; this finding indicates that Academic achievement appeared as a significant factor of Mental health among non-hostlers. The table indicates a significant positive correlation exists between Academic achievement and mental health among non-hostlers. It means that when Academic achievement increases mental health also increases and when Academic achievement decreases Mental health also decreases. 
The table indicates the Mean, $\mathrm{SD}, \mathrm{SE}_{\mathrm{D}}$ and $\mathrm{t}$ value of hostlers and non-hostlers in terms academic achievement and mental health.

\begin{tabular}{|c|c|c|c|c|c|}
\hline Groups & $\mathbf{N}$ & Mean & SD & $\mathbf{S E}_{\mathbf{D}}$ & t-value \\
\hline $\begin{array}{l}\text { Academic Achievement } \\
\text { Hostlers }\end{array}$ & 80 & 331.00 & 15.394 & \multirow{2}{*}{2.10} & \multirow{2}{*}{$10.66 * *$} \\
\hline $\begin{array}{l}\text { Academic Achievement } \\
\text { Non-Hostlers }\end{array}$ & 80 & 308.60 & 10.813 & & \\
\hline Mental Health Hostlers & 80 & 213.80 & 16.096 & \multirow[b]{2}{*}{2.01} & \multirow[b]{2}{*}{$6.36 * *$} \\
\hline $\begin{array}{l}\text { Mental Health Non- } \\
\text { Hostlers }\end{array}$ & 80 & 201.00 & 8.1750 & & \\
\hline
\end{tabular}

This table shows the mean difference between hostlers and non-hostlers in terms academic achievement and mental health. It is clearly shown that hostlers show better academic achievement $($ Mean $=331)$ as compared to non-hostlers (Mean $=308.60)$. The $t$-value was found to be $10.66^{* *}$ which is significant at 0.01 and 0.05 levels. The table also reveals that hostlers are having better mental health $($ Mean $=213.80)$ as compared to non-hostlers (Mean= 201). The tvalue was found to be $6.36^{* *}$ which is significant at 0.01 and 0.05 levels.

\section{CONCLUSION}

The paper analyses mental health status of hostlers and non hostlers in relation to their academic achievement. The result findings reveal that hostlers have better mental health as compared to non-hostlers and academic achievement of hostlers is high as compared to non-hostlers. It is because hostlers are living in competitive, informative and educative environments and enjoy better facilities in hostels which lead to their higher academic achievements and to success in life. As the present world is plagued by the problems like oppression, exploitation, social and political crisis, trauma etc, so it is necessary to succeed in the present world and hostels play important roles in achieving success of individuals.

\section{REFRENCES}

Bussan, Kerri Anne (2010). Youth Mental Health. Chisholm Health Ethics, Bulletin, Vol. 16, No. 1, Spring 2010: 1-4.Cokes, C \& Kornblum, W 2010, Journal of Black Studies, vol. 34, no. 1, pp. 24-35.

B.C Minister of Health's Advisory Council on Mental Health (2002)

Caria, M. P., Bellocco, R., Zambon, A., Horton, N. J., \& Galanti, M. R. (2009).

M., Eamon; \& Keeman (2005). Social-demographic, school, neighborhood, and Parenting influences on academic achievement of Latino young adolescents.

Journal of Youth and Adolescence, 34(2), 163-175. ction, 104(4), 661-668. 
Fernando S., (1995); Mental Health in a Multiethnic Society: a Multi-disciplinary Handbook, Routledge, UK.

Garrett, H. E. (1981). Statistics in Psychology and Education. Bombay: Vaklis, Feffer and Simons Pvt. Ltd.

Rozumah. B., \& L., Tom. L., (1998). Factors related to the quality of the home environment and children's achievement. Journal of Family Issues, 19(4), 375-403.

T. K. Logan and J. Cole,(2007). "The impact of partner stalking on mental health and protective order outcomes over time," Violence and Victims, vol. 22, p.546-562, 2007.

World Health Organization,(2010). Preventing Intimate Partner and Sexual Violence Against Women: Taking Action and Generating Evidence, World Health Organization, Geneva, Switzerland.

Mahsome Azimifar, 2013 the relationship between emotional intelligence and academic achievement among Iranian students in elementary 2. 